\title{
Glycan Shielding and Modulation of Hepatitis C Virus Neutralizing Antibodies
}

\author{
Muriel Lavie ${ }^{1}$, Xavier Hanoulle ${ }^{2}$ and Jean Dubuisson ${ }^{1 *}$ \\ 1 University of Lille, CNRS, INSERM, CHU Lille, Institut Pasteur de Lille, U1019 - UMR 8204 - CIIL - Center for Infection \& \\ Immunity of Lille, Lille, France, ${ }^{2}$ University of Lille, CNRS, UMR 8576, UGSF, Unité de Glycobiologie Structurale et \\ Fonctionnelle, Lille, France
}

\section{OPEN ACCESS}

Edited by: Steven Foung,

Stanford University,

United States

Reviewed by:

Mirjam B. Zeisel,

Institut National de la Santé

et de la Recherche Médicale

(INSERM), France

Pietro Speziale,

Università degli studi di

Pavia, Italy

*Correspondence:

Jean Dubuisson

jean.dubuisson@ibl.cnrs.fr

Specialty section:

This article was submitted

to Vaccines and

Molecular Therapeutics,

a section of the journal

Frontiers in Immunology

Received: 26 February 2018

Accepted: 12 April 2018

Published: 27 April 2018

Citation:

Lavie $M$, Hanoulle $X$ and Dubuisson J (2018) Glycan

Shielding and Modulation of Hepatitis C Virus Neutralizing Antibodies.

Front. Immunol. 9:910. doi: 10.3389/fimmu.2018.00910
Hepatitis C virus (HCV) envelope glycoprotein heterodimer, E1E2, plays an essential role in virus entry and assembly. Furthermore, due to their exposure at the surface of the virion, these proteins are the major targets of anti-HCV neutralizing antibodies. Their ectodomain are heavily glycosylated with up to 5 sites on E1 and up to 11 sites on E2 modified by $\mathrm{N}$-linked glycans. Thus, one-third of the molecular mass of E1E2 heterodimer corresponds to glycans. Despite the high sequence variability of E1 and E2, N-glycosylation sites of these proteins are generally conserved among the seven major HCV genotypes. N-glycans have been shown to be involved in E1E2 folding and modulate different functions of the envelope glycoproteins. Indeed, site-directed mutagenesis studies have shown that specific glycans are needed for virion assembly and infectivity. They can notably affect envelope protein entry functions by modulating their affinity for HCV receptors and their fusion activity. Importantly, glycans have also been shown to play a key role in immune evasion by masking antigenic sites targeted by neutralizing antibodies. It is well known that the high mutational rate of HCV polymerase facilitates the appearance of neutralization resistant mutants, and occurrence of mutations leading to glycan shifting is one of the mechanisms used by this virus to escape host humoral immune response. As a consequence of the importance of the glycan shield for HCV immune evasion, the deletion of N-glycans also leads to an increase in E1E2 immunogenicity and can induce a more potent antibody response against $\mathrm{HCV}$.

Keywords: hepatitis C virus, neutralizing antibodies, glycosylation, humoral immune response, glycoproteins

\section{INTRODUCTION}

With approximately 70 million people chronically infected worldwide, hepatitis C virus (HCV) is a major health burden. In most cases, HCV establishes chronic infection that can lead to the development of cirrhosis and hepatocellular carcinoma. For a long time, standard treatment for HCV infection consisted in a non-specific combination therapy with pegylated interferon and ribavirin, which was relatively toxic and effective in half of treated patients. Advances in in vitro and in vivo

Abbreviations: HCV, hepatitis C virus; HVR1, hypervariable region 1; HCVpp, HCV pseudoparticles; HCVcc, cell culturederived HCV; ER, endoplasmic reticulum; SR-BI, scavenger receptor BI; mAb, monoclonal antibody; Glc, glucose; Man, mannose; GlcNAc, $N$-acetylglucosamine. 
HCV infection systems resulted in a great increase of our understanding of the HCV life cycle. This led to the development of several successful direct acting antivirals that allow for the achievement of high HCV clearance rates (>90\%). However, the high cost of these antivirals therapy precludes their accessibility to the large majority of $\mathrm{HCV}$-infected patients (1). In this context, the development of a preventive HCV vaccine would constitute the most cost-effective means to limit HCV spread. Studies have shown that a successful HCV vaccine would induce the production of neutralizing antibodies and a potent HCV-specific T cell response (2). However, a key challenge in HCV vaccine development is to overcome the high diversity of this virus. Several vaccine candidates targeting the envelope glycoproteins have been shown to induce strong humoral and cellular immune response in animal models or clinical trials in humans. However, their efficiency was limited by viral escape from immune response due to the high genetic variability of the virus (2-5). In this context, the design of an efficient vaccine will require a good knowledge of the strategies used by the virus to escape host immune response. One of these strategies is the presence of a glycan shield that protects E2 conserved epitopes from neutralizing antibodies. Here, we present the glycosylation of HCV envelope glycoproteins and we review the different aspects of the modulation of neutralizing antibodies by HCV glycan shield.

\section{GLYCOSYLATION OF HCV ENVELOPE PROTEINS}

\section{Distribution of E1 and E2 N-Glycans}

E1 and E2 are highly glycosylated with $\mathrm{N}$-glycans representing one-third of the heterodimer mass. $\mathrm{N}$-glycosylation occurs on the asparagine (Asn) residue belonging to aparagine- $\mathrm{X}$-serine/ threonine (Asn-X-Thr/Ser) motifs where $\mathrm{X}$ denotes any residue but Proline. In most genotypes, E1 contains four conserved glycosylation sites that are located at amino acid position 196 (E1N1), 209 (E1N2), 234 (E1N3), and 305 (E1N4) in genotype 1a H77 strain (Figure 1). However, an additional glycosylation site is present at position 250 in genotypes $1 \mathrm{~b}$ and 6, or at position 299 in genotype $2 \mathrm{~b}(6)$.

Up to 11 glycosylation sites can be detected in most E2 glycoprotein sequences. Nine of them are conserved across HCV genotypes, and they are located at positions 417 (E2N1), 423 (E2N2), 430 (E2N3), 448 (E2N4), 532 (E2N6), 556 (E2N8), 576 (E2N9), 623
(E2N10), and 645 (E2N11) in the H77 reference strain (Figure 1). The two other glycosylation sites are also conserved in most genotypes except in genotype $1 \mathrm{~b}$ for the site at position 476 (E2N5) and in genotypes 3 and 6 for the site at position 540 (E2N7). Thus, despite high sequence variability in HCV, the majority of $\mathrm{N}$-glycosylation sites are highly conserved, suggesting that glycans play a major role in the HCV life cycle. Importantly, all these sites have been confirmed to be occupied by glycans $(7,8)$.

In a minority of $\mathrm{HCV}$ genomes, additional glycosylation sites can also be observed. For instance, another glycosylation site has been reported to be present in the intragenotypic hypervariable region HVR495 of E2 in a minority of genotype 3a isolates from Pakistani patients (9). An additional glycosylation site has also been shown to appear in hypervariable region 1 (HVR1) after selection of a mutant resistant to monensin treatment in cell culture (10). The appearance of such natural or selected glycans suggests that HCV can adapt to environmental changes by generating novel glycosylation sites.

\section{Type of Glycans Associated With E1 and E2 Glycoproteins}

$\mathrm{N}$-linked glycosylation occurs by the transfer en bloc of a Glc3Man9GlcNAc2 oligosaccharide from a lipid intermediate to an Asn residue in the consensus sequence Asn-X-Thr/Ser of a nascent protein. Three major types of $\mathrm{N}$-glycans can be observed on glycoproteins. The first type corresponds to high mannose glycans which are composed of two $\mathrm{N}$-acetylglucosamine molecules linked to several mannoses residues; the second type of glycans are complex oligosaccharides which are mainly composed of two $\mathrm{N}$-acetylglucosamines, galactose and can contain sialic acid and fucose. Hybrid type glycans constitute the third type of $\mathrm{N}$-glycans. They are composed of $\mathrm{N}$-acetylglucosamine, galactose, mannose, and can contain sialic acid. Complex and hybrid glycans are generated during the transit of the protein through the Golgi compartment by addition or removal of sugar residues by specific enzymes. It has been shown that cell-associated E1E2 mainly display high-mannose-type oligosaccharides, which is in agreement with their retention in the endoplasmic reticulum (ER) of infected cells (11). Furthermore, the characterization of E2 glycosylation sites by mass spectrometry confirmed that the majority of these sites are occupied by high mannose glycans on a recombinant form of the glycoprotein (12).

Since they are assembled in the ER, HCV particles have to cross the secretory pathway before being released by infected

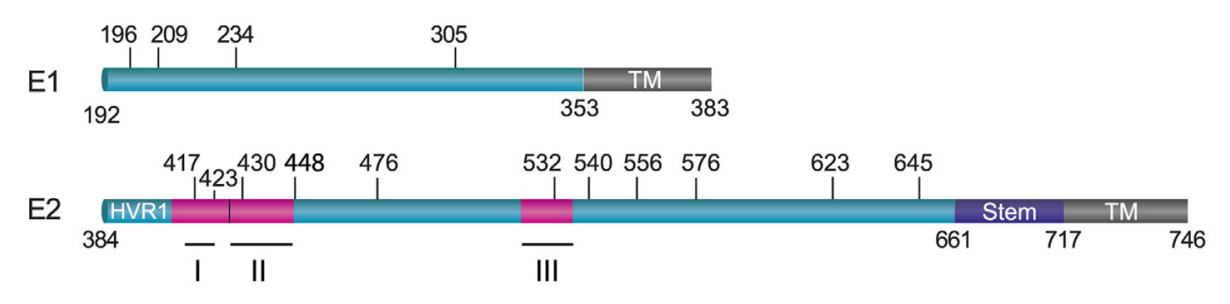

FIGURE 1 | Position of N-linked glycans on hepatitis C virus envelope glycoproteins. E1 and E2 are schematically represented by boxes with their transmembrane domains shown in brown. The glycosylation sites and their position are indicated by vertical bars (on reference strain $\mathrm{H} 77$ ). The localization of three major neutralizing epitopes on E2 (I: 412-423; II: 427-446; III: 523-535) is also shown. 
cells. During this process, the glycoproteins associated with the virions are modified by cellular glycosidases and glycosyl transferases. In the absence of a cell culture system for HCV, the first evidence of glycan modifications linked to secretion of viral particles came from the characterization of retroviral pseudotypes harboring $\mathrm{HCV}$ envelope glycoproteins [HCV pseudoparticles (HCVpp)] $(13,14)$. However, later on, different patterns of glycosylation have been observed between cell culture-derived HCV (HCVcc) and HCVpp associated glycoproteins (11). Thus, HCVccassociated E1E2 heterodimers contain both high-mannose and complex type N-linked glycans, whereas HCVpp associated E1E2 display a majority of complex-type glycans. Complex glycans are hallmarks of protein transit through the Golgi apparatus since they result from the processing of high-mannose-type glycans by Golgi glycosidases and glycosyltransferases (15). The incomplete maturation of $\mathrm{HCVcc}$ E1E2 glycans indicates that some glycans are not accessible to Golgi enzymes. By contrast, HCVpp-associated glycans are more efficiently matured. These results are likely due to differences in the assembly process of HCVpp and HCVcc. Indeed, HCVcc assemble in an ER-derived compartment (16), whereas HCVpp assemble in a post-Golgi compartment (17). Therefore, in the HCVpp system, E1E2 transit through the Golgi compartment without any other viral components and are thus fully accessible to Golgi enzymes. In the HCVcc system, E1E2 are already associated with nascent viral particles when they travel through the secretory pathway and might thus be less accessible to Golgi enzymes.

It is worth noting that, in addition to $\mathrm{N}$-linked sugars, O-linked glycans have also been identified on a recombinant form of E2 protein (18). Four of these O-linked carbohydrates were identified in HVR1 and two in the core structure of E2 (Thr473 and Thr518). However, these types of glycans were not found by another group which used a similar approach for their detection (19). Since the two groups used an E2 protein from different genotypes, one cannot exclude genotype differences in terms of O-glycosylation, but no O-linked glycans were reported on the structure of E2 $(20,21)$. It is also possible that the O-glycans observed by Braütigam and coworkers (18) are present on a misfolded structure of E2.

\section{N-Glycans on E1 and E2 Structures}

In 2014, the crystal structure of the N-terminal sequence (residues 192-270) of E1 expressed in the absence of E2 was obtained. This polypeptide contained N-glycosylation sites E1N1 and E1N2, but the E1N3 N-glycosylation site was removed from the sequence by mutagenesis. However, to facilitate the crystallization process, the molecule was produced in the presence of an N-glycosylation inhibitor (22). In this structure, the N-terminus forms a betahairpin followed by a domain composed of a 16 amino acid long alpha-helix flanked by a three strands anti-parallel beta-sheet. The oligomeric arrangement displays two types of dimers. In the first type, the two monomers interface is formed by the interaction of the N-terminal beta-hairpin forming an anti-parallel beta-sheet and by hydrogen bonding between $\mathrm{Y} 1$ residue and the $N$-acetyl-D-glucosamine of the E1N1 glycosylation site. The second dimer interface corresponds to a six-stranded beta-sheet formed from two sets of three strands from two monomers that is stabilized by two disulfide bridges.

The structure of the central E2 ectodomain was solved by two independent groups in 2013 and 2014 (20, 21). The obtained structures were very similar [residues $412-645$ of E2 of E2 from $\mathrm{H} 77$ isolate of genotype 1a in Kong et al. (20); residues 456-656 of E2 from J6 isolates of genotype 2a in Khan et al. (21)]. E2 core shows a globular structure. Indeed, it is composed of a central immunoglobulin fold beta domain as found in other viral envelope proteins. This central beta sandwich is flanked by front and back layers consisting of loops, short helices, and beta sheets. Most of the $\mathrm{N}$-glycosylation sites present on E2 could be observed in the crystal structure (H77 strain sequence) obtained by Kong and collaborators (4MWF) (20). Only E2N1, E2N5, E2N4, and E2N9 are absent due to truncations or mutations introduced in the E2 sequence to facilitate crystallization (20). The majority of the N-linked glycans were disordered in the crystal structure. Only glycan N430 could be modeled as Man6GlcNAc2. E2 structure revealed that 7 of the $11 \mathrm{~N}$-linked glycans form an extensive glycan shield that masks E2 neutralizing epitopes (Figure 2) (20). Residues E2N7, E2N8, E2N10, and E2N11 were also modeled in the final E2 core structure obtained by Khan and collaborators (21). They were located on the periphery of the core on a highly basic surface.

\section{ROLE OF E1E2 N-GLYCANS IN THE HCV LIFE CYCLE}

\section{Role of the N-Glycans of E1 and E2 in the Early Secretory Pathways}

One of the major roles of N-linked glycans is their involvement in protein folding (15). Indeed, the presence of large polar saccharides directly influences the local orientation of the protein. In addition, $\mathrm{N}$-glycans indirectly affect protein folding through their interaction with the ER chaperones, calnexin, and calreticulin. Calnexin and calreticulin are lectin-like chaperones, which show an affinity for monoglucosylated $\mathrm{N}$-linked oligosaccharides $(15,25)$. Calnexin has been shown to interact with HCV envelope glycoproteins (26-28) and has been suggested to be involved in the folding of E1E2 envelope glycoproteins. In the case of $\mathrm{HCV}$, several N-linked glycans of E1 (E1N1 and E1N4) and E2 (E2N7, $\mathrm{E} 2 \mathrm{~N} 8$, and E2N10) have been shown to play a role in E1 and E2 folding and heterodimerization. The alteration of the folding observed for these mutants was not due to a lack of recognition by the calnexin chaperone (8).

\section{Functions of Virion-Associated Glycans}

The extended glycosylation of E1 and E2 suggests that interactions between lectin receptors and virus might play a role during $\mathrm{HCV}$ infection. In agreement with this hypothesis, several lectin receptors have been shown to participate in HCV entry (29). Thus, $\mathrm{HCV}$ is thought to initially bind the endothelium of the liver via the mannose-binding lectins L-SIGN and the dendritic cells via DC-SIGN. Both cell surface proteins are believed to function as capture receptors that concentrate the virus before subsequent interaction with the hepatocytes (29). HCV interaction with 


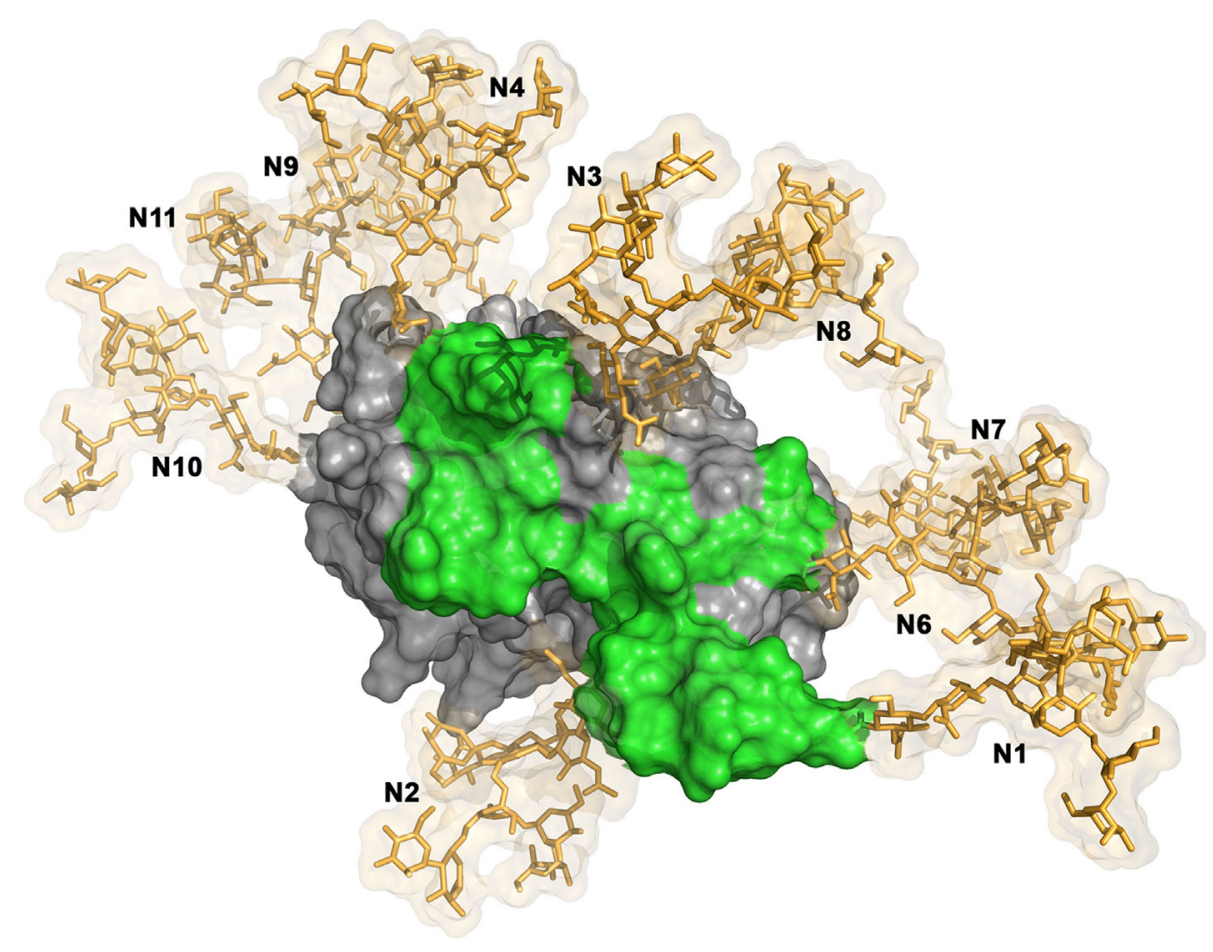

FIGURE 2 | Glycan shield masking E2 neutralizing epitopes. The model of E2 structure is composed by the E2 core structure (PDB ID: 4MWF) (20) and its N-terminal antigenic region 412-423 (PDB ID: 4DGY) (23). The E2 structural model has been built in a similar way than in Fuerst et al. (24). The hypervariable region 1 located at the N-terminus of E2 is not shown. The E2 molecular surface is displayed in gray and its neutralizing epitopes are highlighted in green. High mannose N-glycans (Man9GlcNac2) have been modeled at the $10 \mathrm{~N}$-glycosylation sites available in the E2 structural model using the Glycoprotein Builder tool of the GLYCAM-webserver (http://glycam.org), with an energy minimization step. The glycans (N1, N2, N3, N4, N6, N7, N8, N9, N10, and N11) are shown in sticks representation (in gold) with their transparent molecular surface. The figure was generated with PyMOL (The PyMOL Molecular Graphics System, Version 1.83 Schrödinger, LLC).

hepatocytes is then mainly promoted by scavenger receptor BI (SR-BI), CD81, and the tight-junction proteins claudin-1 and occludin. Interestingly, the type of glycans associated with E1E2 proteins has been shown to influence their binding affinity for lectin receptors as well as for the non-lectin receptors (30).

Site-directed mutagenesis in HCVpp and HCVcc systems enabled to further characterize the functional role of N-glycans associated with HCV envelope proteins $(8,31,32)$ (Table 1). These studies confirmed that several glycans (E1N1, E2N8, and E2N10) are involved in E1E2 folding and heterodimerization. Glycans can also modulate E1E2 entry functions by affecting the affinity of the envelope proteins for receptors. Indeed, mutation of E2N6 glycosylation site led to an increase in HCVcc infectivity. Moreover, this mutant was more sensitive to infectivity inhibition by a soluble form of the CD81 large extracellular loop (32). In agreement with these data, a soluble form of E2 devoid of E2N6 glycan exhibited a higher affinity for CD81 (31). Altogether, these data suggest that the improved infectivity of E2N6 mutant is due to its increased affinity for CD81. Interestingly, the loss of E2N6 glycosylation site has been observed among naturally occurring HCVcc variants adapted to cell culture $(33,34)$. It is worth noting that on the 3D structure of E2, the CD81-binding site is surrounded by glycans (20), and the removal of the glycan at position E2N6 likely provides more space for CD81 binding.
By contrast, mutation of the E2N7 glycosylation site led to a strong decrease in $\mathrm{HCVcc}$ infectivity without affecting viral particle secretion, suggesting that the glycan present at this position modulates virus entry (32). However, the exact mechanism was not determined. Furthermore, the role of E2N7 glycan in virus entry is likely genotype specific since this glycan site is absent in genotype 3 and 6 .

\section{Different Roles for $\mathrm{N}$-Glycans in HCVpp and HCVcc Systems}

Noteworthy, in some cases, envelope glycoprotein entry functions were differently affected by glycan loss in HCVcc and HCVpp systems (32). It is the case for the E2N2 or E2N4 mutations that slightly affected HCVcc infectivity but abolished HCVpp infectivity (32). Several studies could also demonstrate differences between the entry functions of envelope proteins in HCVpp and HCVcc systems (35-39). These differences might be due to the distinct assembly processes of HCVcc and HCVpp particles, that lead to different glycan processing and different organization of the proteins at the virion surface $(11,14,17,40)$. Moreover, the association of $\mathrm{HCVcc}$ with lipoproteins might also account for the differences in the properties of E1E2 in HCVpp and HCVcc systems $(40,41)$. Importantly, despite differences in glycosylation 
TABLE 1 | Summary of the features of HCV glycosylation mutants [adapted from Helle et al. (92)].

\begin{tabular}{|c|c|c|c|c|}
\hline Virus & $\begin{array}{c}\text { HCVcc } \\
\text { Infectivity }^{\mathrm{a}}\end{array}$ & $\begin{array}{c}\text { HCVpp } \\
\text { infectivity }{ }^{\mathrm{a}, \mathrm{b}}\end{array}$ & $\begin{array}{l}\text { Core } \\
\text { release }^{c}\end{array}$ & $\begin{array}{l}\text { Sensitivity to } \\
\text { neutralization }^{\text {d }}\end{array}$ \\
\hline wt & +++ & +++ & ++ & + \\
\hline \multicolumn{5}{|l|}{ Mutant } \\
\hline E1N1 & $+/-$ & ++ & - & $\mathrm{ND}(+)$ \\
\hline E1N2 & ++ & + & + & ND (+) \\
\hline E1N3 & +++ & ++ & ++ & $N D(+)$ \\
\hline E1N4 & ++ & + & $+/-$ & ND (+) \\
\hline E2N1 & +++ & ++ & ++ & ++ \\
\hline E2N2 & ++ & $-(-)$ & ++ & $++^{e}$ \\
\hline E2N3 & + & +++ & + & ND (+) \\
\hline E2N4 & ++ & $-(-)$ & + & $++^{e}$ \\
\hline E2N5 & ++ & ++ & ++ & + \\
\hline E2N6 & +++ & ++ & ++ & ++ \\
\hline E2N7 & $+/-$ & $+++(+)$ & + & ND (-) \\
\hline E2N8 & - & - & $+/-$ & ND \\
\hline E2N9 & +++ & +++ & ++ & + \\
\hline E2N10 & - & - & - & ND \\
\hline E2N11 & + & + & $+/-$ & ++ \\
\hline HVR495 & +++ & + & ND & ++ \\
\hline
\end{tabular}

aPercentage of infectivity relative to the wild type (wt): +++, >90\%; ++, between 30 and $90 \%$; +, between 10 and $30 \%$; +/-, between 2 and 10\%; -, <2\%.

bInfectivity of HCVpp of genotype 1a and 3a for the HVR495 glycan (9). The results in brackets are obtained for genotype 2 a HCVpp.

'Percentage of core release relative to the $w t:++,>75 \%$; +, between 30 and $75 \%$; $+/-$, between 12 and $30 \%$; - < $<12 \%$.

${ }^{d}$ Sensitivity to antibody neutralization: + , similar to the $w t ;++$, more than fourfold increase in sensitivity to neutralization with most antibodies tested; -, decrease in sensitivity to neutralization. The values in brackets were obtained for genotype 1a HCVpp only.

${ }^{e}$ Results obtained with the HCVcc system only.

ND, not determined; HCV, hepatitis C virus; HCVpp, HCV pseudoparticles; HCVcC, cell culture-derived $\mathrm{HCV}$.

patterns, there is a strong correlation between HCVpp and HCVcc in their sensitivity to antibody neutralization, indicating that the type of glycans associated with HCV envelope proteins might not drastically affect the recognition of neutralizing epitopes (39).

\section{Antiviral Strategies Targeting E1E2 N-Glycans}

The importance of N-glycans for the folding of E1E2 envelope proteins, for HCV entry and for the protection of the virus from neutralizing antibodies make them promising targets for antiviral strategies. Accordingly, many studies have shown the antiviral activity against $\mathrm{HCV}$ of several carbohydrates binding agent (CBA), such as cyanovirin- $\mathrm{N}$, griffithsin, or scytovirin lectins, as well as pradimicin-A (42-47). Surprisingly, the selection of resistance mutations by propagating $\mathrm{HCVcc}$ in the presence of increasing doses of CBA did not lead to the appearance of mutations in the envelope glycoproteins. Resistance was rather conferred by mutations in the core and the non-structural proteins (48), suggesting indirect mechanisms of resistance.

In agreement with the functional role of glycosylation in the HCV life cycle, inhibition of $\alpha$-glycosidases I and II, that are essential for $\mathrm{N}$-linked glycan processing, impaired $\mathrm{HCV}$ production. Indeed, treatment of infected cells with competitive inhibitors of $\alpha$-glucosidases led to the degradation of E2 and to the consequent inhibition of HCV assembly and secretion
$(49,50)$. Despite the great potential of glycosidase inhibitors as broad-spectrum antiviral drugs, their clinical development has been hampered by their relatively low efficacy. Such a compound like celgosivir showed only a modest antiviral effect in chronically $\mathrm{HCV}$-infected patients in a phase II clinical trial (5\% of the tested patients experienced a 10 -fold reduction in viremia) (51).

\section{HCV GLYCAN SHIELD AND HOST IMMUNE RESPONSE}

\section{Neutralizing Determinants in HCV Envelope Glycoproteins}

Neutralizing antibodies inhibit viral infection by binding to viral particles. This leads to the blockade of the interaction with receptors or prevents the envelope glycoproteins conformational changes required for the fusion step. E2 envelope glycoprotein is the main target of the humoral immune response against $\mathrm{HCV}$ (52). The importance of neutralizing antibodies to eliminate $\mathrm{HCV}$ infection has been shown in a humanized mouse model (53). Several regions of E2 are targeted by neutralizing antibodies. Among them the first 27 amino acids of E2 that correspond to HVR1, a highly variable region of the protein, play important roles in interaction with the HCV co-receptor SR-BI, in viral fitness, and in assembly and release of viral particle (54-57). However, antibodies targeting HVR1 exhibit poor cross-neutralization potency across HCV genotypes due to the high variability of this region (58). HVR1 deletion mutants are more susceptible to neutralization by monoclonal antibodies (mAbs) and patient sera $(54,56)$. Since CD81-binding site is the main target of neutralizing antibodies, this finding suggests that HVR1 masks this site on E2. Additional lines of evidence gave rise to this hypothesis. Indeed, no interaction could be observed between HCV and CD81 at the cell surface in the absence of SR-BI (59). This led to the proposal that HVR1 shields CD81-binding site and that the interaction of SR-BI with HVR1 allows for the exposure of CD81-binding region on $\mathrm{E} 2(54,60,61)$.

Interestingly, most antibodies endowed with broad neutralizing activity target conserved conformational epitopes on E2 and inhibit the interaction between E2 and CD81 (52). Neutralizing antibodies targeting the CD81-binding site either recognize linear epitopes located in amino acids 412-423, conformational epitopes with contact residues located between residues 523 and 535 or epitopes spanning these two CD81-binding regions (Figure 1). Importantly, the most potent neutralizing murine antibodies target linear epitopes covering residues 412-423, whereas antibodies isolated from $\mathrm{HCV}$-infected patient sera targeting this epitope are rare. By contrast, most human neutralizing antibodies recognize conformational epitopes centered on the CD81-binding residues W529, G530, and D535 (62).

While most neutralizing antibodies target CD81-binding sites, some neutralizing antibodies targeting conserved epitopes overlapping the SR-BI binding site have been described (63). Interestingly, a synergistic neutralization has been observed between the HEPC74 and the HEPC98 antibodies that, respectively, block E2-CD81 and E2-SR-BI binding (64). Moreover, the pairing of these antibodies showed an enhanced neutralizing breadth and 
their mechanisms of action were found to be independent. Thus, the reliance of $\mathrm{HCV}$ on multiple cellular receptors constitutes a source of vulnerability that could be exploited in the design of an efficient vaccine.

Over the past few years, the interaction between E2 and several different neutralizing antibodies could be precisely mapped by resolution of the crystal structure of E2 peptide-antibody complexes $(23,65-67)$, providing a molecular framework to better understand HCV neutralization.

\section{Role of Glycosylation in HCV Resistance to Neutralization}

The most common mechanism of evasion to antibody neutralization is mutational escape. For its replication, $\mathrm{HCV}$ relies on a RNA-dependent RNA polymerase that lacks proofreading capabilities and allows a high replication rate of the virus. These features result in the generation of a high diversity of viral variants that constitute quasispecies (68). The neutralization escape variants contained in the viral population have a selective advantage over sensitive variants and can become the dominant circulating strain $(52,69-71)$.

Apart from its high genetic heterogeneity, HCV has developed various ways to escape the host immune response. One of them is a protection by a glycan shield that reduces the immunogenicity of the envelope proteins and masks conserved neutralizing epitopes at their surface. Indeed, glycans associated with viral envelope proteins are synthesized by the host cell and are recognized as self-structures. Thus, many viruses that impact human health use glycosylation to evade the host immune response (72).

Characterization of $\mathrm{N}$-glycosylation mutants in the $\mathrm{HCVcc}$ system has shown that at least five glycans (E2N1, E2N2, E2N4, E2N6, and E2N11) on E2 reduce the sensitivity of the virus to neutralization (32). Indeed, the absence of one of these glycans leads to an increase in the sensitivity of the virus to neutralization by antibodies purified from HCV positive patients or mAbs. These data further confirm those obtained with the HCVpp system for E2N1, E2N6, and E2N11 mutants $(8,31)$. However, in this latter system, E2N2 and E2N4 mutations resulted in the production of non-infectious particles. HCV glycans have been shown to mask the neutralizing activity of mAbs targeting conserved epitopes while having no effect on the recognition of HVR1 epitopes (32). Moreover, E2N1, E2N2, E2N4, and E2N6 modulate the inhibition of $\mathrm{HCV}$ infectivity by a soluble form of CD81 receptor. Since most broadly neutralizing mAbs target CD81-binding site on E2, these results suggest that this site is the neutralizing antibody target that is protected by $\mathrm{N}$-glycans. In agreement with these data, the modeling of N-linked glycans on E2 core structure confirmed the presence of an extensive glycan shield that masks CD81-binding site (Figure 2) (20). Since HVR1 is also thought to hide CD81-binding site, it would be interesting to determine whether glycans and HVR1 shielding effects are additive.

E1 glycosylation had no effect on the sensitivity of HCVpp to neutralization with purified antibodies from $\mathrm{HCV}$ positive patient sera (6). However, this result could be due to the fact that the neutralizing immune response against $\mathrm{HCV}$ is dominated by anti-E2 antibodies. Thus, it would be interesting to determine the role of E1 glycans in the protection of HCV from neutralization by using anti-E1 neutralizing mAbs. Unfortunately, the availability of such antibodies remains very limited $(73,74)$.

\section{N-Glycosylation Escape Mutants}

Further highlighting the importance of N-linked glycosylation in shielding E2 epitopes from recognition by broadly neutralizing antibodies, Pantua and collaborators (75) observed the appearance of escape mutants from AP33 neutralizing mAb that exhibited a glycan shift. Indeed, in vitro resistance selection led to the identification of N417S and N417T HCVcc variants that were resistant to broadly neutralizing antibodies targeting the 412-423 E2 epitope. The two variants presented a glycosylation shift from N417 (E2N1) to N415. N415 residue has been shown to be important for the recognition of the 412-423 epitope by AP33 and HCV1 neutralizing antibodies. Moreover, N415 appeared to be buried in the antibody-peptide interface in the crystal structure of 412-423 epitope in complex with several neutralizing antibodies $(66,67,75)$. Consequently, attachment of a glycan at N415 and not at N417 would create a steric bulk that would abrogate AP33 and HCV1 binding. These data led to the conclusion that the glycosylation shift from residue N417 to N415 causes HCV resistance to AP33 and HCV1 neutralizing antibodies (75).

Interestingly, this glycosylation shift could also be observed in the absence of neutralizing antibody selection, thus showing that residue 417 is polymorphic (N, S, or T) (76-78). Furthermore, in a minority of genotype $3 \mathrm{a}$ isolates, an additional glycosylation site appears in the intragenotypic hypervariable region HVR495, which has been shown to provide some protection against neutralizing antibodies (9). Therefore, as previously described for HIV, glycosylation shift is another mechanism leading to the appearance of HCV resistance to neutralizing antibodies (79). However, as compared to HIV, this glycosylation shift remains very limited in HCV as determined by the analysis of patient sequences (80). This is likely due to additional roles played by most HCV glycans in protein folding and/or in other unidentified functions.

However, while conferring resistance to AP33 and HCV1 neutralizing antibodies and a greater in vitro fitness, the glycan shift observed in N417T and N417S led to greater sensitivity to neutralization by other antibodies targeting amino acids 412-423 $(76,77)$. Notably, HC33.1 antibody, which was isolated from an $\mathrm{HCV}$-infected blood donor, could neutralize HCVcc bearing E2 N417T and N417S adaptive mutations more efficiently than HCVcc wild type (wt) (81). The structure of HC33.1 in complex with E2 412-423 epitope revealed a different conformation of the epitope than the beta-hairpin conformation observed in the epitope-AP33 or HCV1 complexes. In this structure, N415 residue was surface exposed such that its glycosylation would not impair antibody binding. Thus, crystallography studies have highlighted the structural flexibility of E2 412-423 epitope that exhibited three different conformations depending on the matched antibody $(23,65-67,82)$. The structural flexibility of this peptide may contribute to reduce its immunogenicity in HCV-infected individuals. Such structural flexibility was also reported for E2 epitope 427-446 that presents different structures when bound to neutralizing or non-neutralizing antibodies (83). Moreover, the crystal structure of E2 core revealed that $60 \%$ of all residues are either disordered or in loops implying considerable 
overall flexibility $(20,21)$. Hence, as proposed for HIV and influenza viruses, conformational flexibility seems to be an additional mechanism used by HCV to evade humoral immunity (84).

\section{Modulation of Immunogenicity by N-Glycosylation}

Since glycans represent one-third of E1E2 heterodimers molecular weight, they are likely to impact the immunogenicity of the envelope proteins. Several data argue in favor of this hypothesis. For instance, removal of E1N4 glycosylation site improved the anti-E1 humoral immune response $(85,86)$. In a similar way, mutation of E2N9 glycosylation site improved the immunogenicity of E2 in a DNA-based vaccination approach (87). Indeed, E2N9 mutant elicited higher E2-specific cytotoxic T lymphocytes activities, T lymphocyte proliferation, and expression of IFN gamma producing $\mathrm{T}$ cells. More recently, mice vaccination with $\mathrm{CpG}$ coupled E1E2 DNA containing mutated E1N2 and E2N3 glycosylation sites induced a higher cellular immune response than wt E1E2. Furthermore, the corresponding serum presented broad neutralizing activity (88). Thus, in this DNA vaccination assay, the naturally poor immunogenicity of E1E2 could be enhanced by deletion of $\mathrm{N}$-glycans combined with the addition of immune activator CpG. Recently, HCV E1E2 heterodimer and a mutant form lacking E2N6 glycosylation site were transiently expressed in an edible crop, lettuce, using Agrobacterium. Produced antigens were used for oral vaccination of mice. The follow up of the immune response induced by HCV heterodimers revealed improved immunogenic properties for the $\mathrm{N}$-glycosylation mutant compared to wt E1E2 (89).

Interestingly, the type of glycans associated with HCV envelope glycoprotein E2 can also affect its immunogenicity. Indeed, as compared to its expression in mammalian cells, E2 produced in insect cells exhibits different glycosylation patterns, which also

\section{REFERENCES}

1. Taherkhani R, Farshadpour F. Global elimination of hepatitis $C$ virus infection: progresses and the remaining challenges. World J Hepatol (2017) 9(33): 1239-52. doi:10.4254/wjh.v9.i33.1239

2. Baumert TF, Fauvelle C, Chen DY, Lauer GM. A prophylactic hepatitis C virus vaccine: a distant peak still worth climbing. J Hepatol (2014) 61(1 Suppl): S34-44. doi:10.1016/j.jhep.2014.09.009

3. Zingaretti C, De Francesco R, Abrignani S. Why is it so difficult to develop a hepatitis C virus preventive vaccine? Clin Microbiol Infect (2014) 20(Suppl 5): 103-9. doi:10.1111/1469-0691.12493

4. Ghasemi F, Rostami S, Meshkat Z. Progress in the development of vaccines for hepatitis C virus infection. World J Gastroenterol (2015) 21(42): 11984-2002. doi:10.3748/wjg.v21.i42.11984

5. Ogholikhan S, Schwarz KB. Hepatitis vaccines. Vaccines (Basel) (2016) 4(1): 1-17. doi:10.3390/vaccines4010006

6. Helle F, Goffard A, Morel V, Duverlie G, McKeating J, Keck ZY, et al. The neutralizing activity of anti-hepatitis $\mathrm{C}$ virus antibodies is modulated by specific glycans on the E2 envelope protein. J Virol (2007) 81(15):8101-11. doi:10.1128/JVI.00127-07

7. Deleersnyder V, Pillez A, Wychowski C, Blight K, Xu J, Hahn YS, et al. Formation of native hepatitis C virus glycoprotein complexes. J Virol (1997) 71:697-704.

8. Goffard A, Callens N, Bartosch B, Wychowski C, Cosset FL, Montpellier-Pala $\mathrm{C}$, et al. Role of $\mathrm{N}$-linked glycans in the functions of hepatitis $\mathrm{C}$ virus envelope glycoproteins. J Virol (2005) 79:8400-9. doi:10.1128/JVI.79.13.8400-8409.2005 lead to increased immunogenicity, as evidenced by the induction of higher titers of broadly neutralizing antibodies (90).

\section{CONCLUSION}

In conclusion, recent studies have greatly contributed to increase the knowledge of the mechanisms used by HCV to evade humoral immune response. The high genetic variability of the virus favors the emergence of neutralization escape variants. Furthermore, the envelope proteins associated glycans and the virus-associated lipoproteins protect conserved immunogenic epitopes from neutralizing antibodies. Although HCV, HIV, and influenza virus share the common feature of shielding neutralizing epitope with glycans, $\mathrm{N}$-glycosylation sites in HCV E1E2 are far less variable than in HIV and influenza, suggesting a different contribution to HCV immune escape (91). Furthermore, the influence of HCV glycans on anti$\mathrm{HCV}$ immune response makes them essential parameters to take into account in the design of an $\mathrm{HCV}$ vaccine based on $\mathrm{HCV}$ envelope glycoproteins. Indeed, while the removal of N-glycans seems to improve the envelope proteins immunogenicity, the contribution of these carbohydrates to E1 and E2 folding makes them essential components for the induction of a biologically relevant E1E2-specific antibody response. One needs, therefore, to keep a good balance between these two functions to optimize the design of a vaccine based on HCV envelope glycoproteins.

Finally, answering questions that remain on the role played by $\mathrm{N}$-glycan in modulation of the humoral immune response will facilitate the design of an effective $\mathrm{HCV}$ vaccine.

\section{AUTHOR CONTRIBUTIONS}

ML wrote the manuscript. XH and JD revised the manuscript. $\mathrm{XH}$ also constructed the structural model.

9. Anjum S, Wahid A, Afzal MS, Albecka A, Alsaleh K, Ahmad T, et al. Additional glycosylation within a specific hypervariable region of subtype $3 \mathrm{a}$ of hepatitis C virus protects against virus neutralization. J Infect Dis (2013) 208(11):1888-97. doi:10.1093/infdis/jit376

10. Feneant L, Potel J, Francois C, Sane F, Douam F, Belouzard S, et al. New insights into the understanding of hepatitis $\mathrm{C}$ virus entry and cell-to-cell transmission by using the ionophore monensin A. J Virol (2015) 89(16):8346-64. doi:10.1128/JVI.00192-15

11. Vieyres G, Thomas X, Descamps V, Duverlie G, Patel AH, Dubuisson J. Characterization of the envelope glycoproteins associated with infectious hepatitis C virus. J Virol (2010) 84:10159-68. doi:10.1128/JVI.01180-10

12. Iacob RE, Perdivara I, Przybylski M, Tomer KB. Mass spectrometric characterization of glycosylation of hepatitis C virus E2 envelope glycoprotein reveals extended microheterogeneity of N-glycans. J Am Soc Mass Spectrom (2008) 19(3):428-44. doi:10.1016/j.jasms.2007.11.022

13. Flint M, Logvinoff C, Rice CM, McKeating JA. Characterization of infectious retroviral pseudotype particles bearing hepatitis $\mathrm{C}$ virus glycoproteins. J Virol (2004) 78(13):6875-82. doi:10.1128/JVI.78.13.6875-6882.2004

14. Op De Beeck A, Voisset C, Bartosch B, Ciczora Y, Cocquerel L, Keck Z,et al. Characterization of functional hepatitis $\mathrm{C}$ virus envelope glycoproteins. J Virol (2004) 78:2994-3002. doi:10.1128/JVI.78.6.2994-3002.2004

15. Helenius A, Aebi M. Intracellular functions of N-linked glycans. Science (2001) 291:2364-9. doi:10.1126/science.291.5512.2364

16. Miyanari Y, Atsuzawa K, Usuda N, Watashi K, Hishiki T, Zayas M, et al. The lipid droplet is an important organelle for hepatitis $\mathrm{C}$ virus production. Nat Cell Biol (2007) 9(9):1089-97. doi:10.1038/ncb1631 
17. Sandrin V, Boulanger P, Penin F, Granier C, Cosset FL, Bartosch B. Assembly of functional hepatitis $\mathrm{C}$ virus glycoproteins on infectious pseudoparticles occurs intracellularly and requires concomitant incorporation of E1 and E2 glycoproteins. J Gen Virol (2005) 86(Pt 12):3189-99. doi:10.1099/ vir.0.81428-0

18. Braütigam J, Scheidig AJ, Egge-Jacobsen W. Mass spectrometric analysis of hepatitis $\mathrm{C}$ viral envelope protein $\mathrm{E} 2$ reveals extended microheterogeneity of mucin-type O-linked glycosylation. Glycobiology (2013) 23(4):453-74. doi:10.1093/glycob/cws171

19. Whidby J, Mateu G, Scarborough H, Demeler B, Grakoui A, Marcotrigiano J. Blocking hepatitis $\mathrm{C}$ virus infection with recombinant form of envelope protein 2 ectodomain. J Virol (2009) 83(21):11078-89. doi:10.1128/JVI. 00800-09

20. Kong L, Giang E, Nieusma T, Kadam RU, Cogburn KE, Hua Y, et al. Hepatitis C virus E2 envelope glycoprotein core structure. Science (2013) 342 (6162):1090-4. doi:10.1126/science.1243876

21. Khan AG, Whidby J, Miller MT, Scarborough H, Zatorski AV, Cygan A, et al. Structure of the core ectodomain of the hepatitis $\mathrm{C}$ virus envelope glycoprotein 2. Nature (2014) 509(7500):381-4. doi:10.1038/nature13117

22. El Omari K, Iourin O, Kadlec J, Sutton G, Harlos K, Grimes JM, et al. Unexpected structure for the N-terminal domain of hepatitis $\mathrm{C}$ virus envelope glycoprotein E1. Nat Commun (2014) 5:4874. doi:10.1038/ncomms5874

23. Kong L, Giang E, Robbins JB, Stanfield RL, Burton DR, Wilson IA, et al. Structural basis of hepatitis $\mathrm{C}$ virus neutralization by broadly neutralizing antibody HCV1. Proc Natl Acad Sci U S A (2012) 109(24):9499-504. doi:10.1073/ pnas.1202924109

24. Fuerst TR, Pierce BG, Keck ZY, Foung SKH. Designing a B cell-based vaccine against a highly variable hepatitis C virus. Front Microbiol (2017) 8:2692. doi:10.3389/fmicb.2017.02692

25. Trombetta ES, Helenius A. Lectins as chaperones in glycoprotein folding. Curr Opin Struct Biol (1998) 8:587-92. doi:10.1016/S0959-440X(98)80148-6

26. Dubuisson J, Rice CM. Hepatitis C virus glycoprotein folding: disulfide bond formation and association with calnexin. J Virol (1996) 70:778-86.

27. Choukhi A, Ung S, Wychowski C, Dubuisson J. Involvement of endoplasmic reticulum chaperones in folding of hepatitis $\mathrm{C}$ virus glycoproteins. J Virol (1998) 72:3851-8.

28. Merola M, Brazzoli M, Cocchiarella F, Heile JM, Helenius A, Weiner AJ, et al. Folding of hepatitis C virus E1 glycoprotein in a cell-free system. J Virol (2001) 75:11205-17. doi:10.1128/JVI.75.22.11205-11217.2001

29. Lozach PY, Burleigh L, Staropoli I, Amara A. The C type lectins DC-SIGN and L-SIGN: receptors for viral glycoproteins. Methods Mol Biol (2007) 379: 51-68. doi:10.1007/978-1-59745-393-6_4

30. Chen PC, Chuang PK, Chen CH, Chan YT, Chen JR, Lin SW, et al. Role of $\mathrm{N}$-linked glycans in the interactions of recombinant HCV envelope glycoproteins with cellular receptors. ACS Chem Biol (2014) 9(7):1437-43. doi:10.1021/ cb500121c

31. Falkowska E, Kajumo F, Garcia E, Reinus J, Dragic T. Hepatitis C virus envelope glycoprotein E2 glycans modulate entry, CD81 binding, and neutralization. J Virol (2007) 81(15):8072-9. doi:10.1128/JVI.00459-07

32. Helle F, Vieyres G, Elkrief L, Popescu CI, Wychowski C, Descamps V, et al. Role of N-linked glycans in the functions of HCV envelope proteins incorporated into infectious virions. J Virol (2010) 84:11905-15. doi:10.1128/JVI. 01548-10

33. Delgrange D, Pillez A, Castelain S, Cocquerel L, Rouillé Y, Dubuisson J, et al. Robust production of infectious viral particles in Huh-7 cells by introducing mutations in hepatitis C virus structural proteins. J Gen Virol (2007) 88: 2495-503. doi:10.1099/vir.0.82872-0

34. Bungyoku Y, Shoji I, Makine T, Adachi T, Hayashida K, Nagano-Fujii M, et al. Efficient production of infectious hepatitis $\mathrm{C}$ virus with adaptive mutations in cultured hepatoma cells. J Gen Virol (2009) 90(Pt 7):1681-91. doi:10.1099/ vir.0.010983-0

35. Johansson DX, Voisset C, Tarr AW, Aung M, Ball JK, Dubuisson J, et al. Human combinatorial libraries yield rare antibodies that broadly neutralize hepatitis C virus. Proc Natl Acad Sci U S A (2007) 104(41):16269-74. doi:10.1073/ pnas.0705522104

36. Kapadia SB, Barth H, Baumert T, McKeating JA, Chisari FV. Initiation of HCV infection is dependent on cholesterol and cooperativity between CD81 and scavenger receptor B type I. J Virol (2007) 81:374-83. doi:10.1128/JVI.01134-06

37. Russell RS, Kawaguchi K, Meunier JC, Takikawa S, Faulk K, Bukh J, et al. Mutational analysis of the hepatitis $\mathrm{C}$ virus $\mathrm{E} 1$ glycoprotein in retroviral pseudoparticles and cell-culture-derived H77/JFH1 chimeric infectious virus particles. J Viral Hepat (2009) 16(9):621-32. doi:10.1111/j.1365-2893.2009. 01111.x

38. Albecka A, Monserret R, Krey T, Tarr AW, Diesis A, Ball JK, et al. Identification of new functional regions in hepatitis $\mathrm{C}$ virus envelope glycoproteins E2. J Virol (2011) 85:1777-92. doi:10.1128/JVI.02170-10

39. Wasilewski LN, Ray SC, Bailey JR. Hepatitis C virus resistance to broadly neutralizing antibodies measured using replication-competent virus and pseudoparticles. J Gen Virol (2016) 97(11):2883-93. doi:10.1099/jgv.0.000608

40. Huang H, Sun F, Owen DM, Li W, Chen Y, Gale M Jr, et al. Hepatitis C virus production by human hepatocytes dependent on assembly and secretion of very low-density lipoproteins. Proc Natl Acad Sci U S A (2007) 104(14): 5848-53. doi:10.1073/pnas.0700760104

41. Gastaminza P, Cheng G, Wieland S, Zhong J, Liao W, Chisari FV. Cellular determinants of hepatitis $\mathrm{C}$ virus assembly, maturation, degradation, and secretion. J Virol (2008) 82(5):2120-9. doi:10.1128/JVI.02053-07

42. Helle F, Wychowski C, Vu-Dac N, Gustafson KR, Voisset C, Dubuisson J. Cyanovirin-N inhibits hepatitis $\mathrm{C}$ virus entry by binding to envelope protein glycans. J Biol Chem (2006) 281:25177-83. doi:10.1074/jbc.M602431200

43. Bertaux C, Daelemans D, Meertens L, Cormier EG, Reinus JF, Peumans WJ, et al. Entry of hepatitis $\mathrm{C}$ virus and human immunodeficiency virus is selectively inhibited by carbohydrate-binding agents but not by polyanions. Virology (2007) 366(1):40-50. doi:10.1016/j.virol.2007.04.008

44. Ashfaq UA, Javed T, Rehman S, Nawaz Z, Riazuddin S. Lysosomotropic agents as HCV entry inhibitors. Virol J (2011) 8:163. doi:10.1186/1743-422X-8-163

45. Meuleman P, Albecka A, Belouzard S, Vercauteren K, Verhoye L, Wychowski C, et al. Griffithsin has antiviral activity against hepatitis $\mathrm{C}$ virus. Antimicrob Agents Chemother (2011) 55(11):5159-67. doi:10.1128/AAC.00633-11

46. Kachko A, Loesgen S, Shahzad-Ul-Hussan S, Tan W, Zubkova I, Takeda K, et al. Inhibition of hepatitis $\mathrm{C}$ virus by the cyanobacterial protein Microcystis viridis lectin: mechanistic differences between the high-mannose specific lectins MVL, CV-N, and GNA. Mol Pharm (2013) 10(12):4590-602. doi:10.1021/ mp400399b

47. Takebe Y, Saucedo CJ, Lund G, Uenishi R, Hase S, Tsuchiura T, et al. Antiviral lectins from red and blue-green algae show potent in vitro and in vivo activity against hepatitis C virus. PLoS One (2013) 8(5):e64449. doi:10.1371/ journal.pone.0064449

48. Izquierdo L, Oliveira C, Fournier C, Descamps V, Morel V, Dubuisson J, et al. Hepatitis $\mathrm{C}$ virus resistance to carbohydrate-binding agents. PLoS One (2016) 11(2):e0149064. doi:10.1371/journal.pone.0149064

49. Steinmann E, Whitfield T, Kallis S, Dwek RA, Zitzmann N, Pietschmann T, et al. Antiviral effects of amantadine and iminosugar derivatives against hepatitis C virus. Hepatology (2007) 46(2):330-8. doi:10.1002/hep.21686

50. Qu X, Pan X, Weidner J, Yu W, Alonzi D, Xu X, et al. Inhibitors of endoplasmic reticulum alpha-glucosidases potently suppress hepatitis $C$ virus virion assembly and release. Antimicrob Agents Chemother (2011) 55(3):1036-44. doi:10.1128/AAC.01319-10

51. Durantel D. Celgosivir, an alpha-glucosidase I inhibitor for the potential treatment of HCV infection. Curr Opin Investig Drugs (2009) 10(8):860-70.

52. Ball JK, Tarr AW, McKeating JA. The past, present and future of neutralizing antibodies for hepatitis C virus. Antiviral Res (2014) 105:100-11. doi:10.1016/j. antiviral.2014.02.013

53. de Jong YP, Dorner M, Mommersteeg MC, Xiao JW, Balazs AB, Robbins JB, et al. Broadly neutralizing antibodies abrogate established hepatitis $\mathrm{C}$ virus infection. Sci Transl Med (2014) 6(254):254ra129. doi:10.1126/scitranslmed. 3009512

54. Bankwitz D, Steinmann E, Bitzegeio J, Ciesek S, Friesland M, Herrmann E, et al. Hepatitis $\mathrm{C}$ virus hypervariable region 1 modulates receptor interactions, conceals the CD81 binding site, and protects conserved neutralizing epitopes. J Virol (2010) 84(11):5751-63. doi:10.1128/JVI.02200-09

55. Bankwitz D, Vieyres G, Hueging K, Bitzegeio J, Doepke M, Chhatwal P, et al. Role of hypervariable region 1 for the interplay of hepatitis $\mathrm{C}$ virus with entry factors and lipoproteins. J Virol (2014) 88(21):12644-55. doi:10.1128/ JVI.01145-14

56. Prentoe J, Serre SB, Ramirez S, Nicosia A, Gottwein JM, Bukh J. Hypervariable region 1 deletion and required adaptive envelope mutations confer decreased dependency on scavenger receptor class B type I and low-density lipoprotein receptor for hepatitis C virus. J Virol (2014) 88(3):1725-39. doi:10.1128/JVI.02017-13

57. Xu Y, Martinez P, Seron K, Luo G, Allain F, Dubuisson J, et al. Characterization of hepatitis $\mathrm{C}$ virus interaction with heparan sulfate proteoglycans. J Virol (2015) 89(7):3846-58. doi:10.1128/JVI.03647-14 
58. Wang Y, Keck ZY, Foung SK. Neutralizing antibody response to hepatitis $C$ virus. Viruses (2011) 3(11):2127-45. doi:10.3390/v3112127

59. Evans MJ, von Hahn T, Tscherne DM, Syder AJ, Panis M, Wolk B, et al. Claudin-1 is a hepatitis $C$ virus co-receptor required for a late step in entry. Nature (2007) 446(7137):801-5. doi:10.1038/nature05654

60. Scarselli E, Ansuini H, Cerino R, Roccasecca RM, Acali S, Filocamo G, et al. The human scavenger receptor class $\mathrm{B}$ type I is a novel candidate receptor for the hepatitis C virus. EMBO J (2002) 21:5017-25. doi:10.1093/emboj/cdf529

61. Dao Thi VL, Granier C, Zeisel MB, Guerin M, Mancip J, Granio O, et al. Characterization of hepatitis $\mathrm{C}$ virus particle subpopulations reveals multiple usage of the scavenger receptor BI for entry steps. J Biol Chem (2012) 287(37):31242-57. doi:10.1074/jbc.M112.365924

62. Owsianka AM, Timms JM, Tarr AW, Brown RJ, Hickling TP, Szwejk A, et al. Identification of conserved residues in the E2 envelope glycoprotein of the hepatitis C virus that are critical for CD81 binding. J Virol (2006) 80(17):8695-704. doi:10.1128/JVI.00271-06

63. Sabo MC, Luca VC, Prentoe J, Hopcraft SE, Blight KJ, Yi M, et al. Neutralizing monoclonal antibodies against hepatitis $\mathrm{C}$ virus $\mathrm{E} 2$ protein bind discontinuous epitopes and inhibit infection at a postattachment step. J Virol (2011) 85(14):7005-19. doi:10.1128/JVI.00586-11

64. Mankowski MC, Kinchen VJ, Wasilewski LN, Flyak AI, Ray SC, Crowe JE Jr, et al. Synergistic anti-HCV broadly neutralizing human monoclonal antibodies with independent mechanisms. Proc Natl Acad Sci U S A (2018) 115(1): E82-91. doi:10.1073/pnas.1718441115

65. Kong L, Giang E, Nieusma T, Robbins JB, Deller MC, Stanfield RL, et al. Structure of hepatitis C virus envelope glycoprotein E2 antigenic site 412 to 423 in complex with antibody AP33. J Virol (2012) 86(23):13085-8. doi:10.1128/JVI.01939-12

66. Potter JA, Owsianka AM, Jeffery N, Matthews DJ, Keck ZY, Lau P, et al. Toward a hepatitis $C$ virus vaccine: the structural basis of hepatitis $C$ virus neutralization by AP33, a broadly neutralizing antibody. J Virol (2012) 86(23):12923-32. doi:10.1128/JVI.02052-12

67. Meola A, Tarr AW, England P, Meredith LW, McClure CP, Foung SK, et al. Structural flexibility of a conserved broadly neutralizing epitope in hepatitis C virus glycoprotein E2. J Virol (2014) 88:2170-80. doi:10.1128/JVI.02190-14

68. Simmonds P, Bukh J, Combet C, Deléage G, Enomoto N, Feinstone S, et al. Consensus proposals for the unified system of nomenclature of hepatitis C virus genotypes. Hepatology (2005) 42:962-73. doi:10.1002/hep.20819

69. Farci P, Shimoda A, Coiana A, Diaz G, Peddis G, Melpolder JC, et al. The outcome of acute hepatitis $\mathrm{C}$ predicted by the evolution of the viral quasispecies. Science (2000) 288(5464):339-44. doi:10.1126/science.288.5464.339

70. von Hahn T, Yoon JC, Alter H, Rice CM, Rehermann B, Balfe P, et al. Hepatitis $\mathrm{C}$ virus continuously escapes from neutralizing antibody and T-cell responses during chronic infection in vivo. Gastroenterology (2007) 132(2):667-78. doi:10.1053/j.gastro.2006.12.008

71. Dowd KA, Netski DM, Wang XH, Cox AL, Ray SC. Selection pressure from neutralizing antibodies drives sequence evolution during acute infection with hepatitis C virus. Gastroenterology (2009) 136(7):2377-86. doi:10.1053/j. gastro.2009.02.080

72. Vigerust DJ, Shepherd VL. Virus glycosylation: role in virulence and immune interactions. Trends Microbiol (2007) 15(5):211-8. doi:10.1016/j.tim.2007.03.003

73. Keck ZY, Sung VM, Perkins S, Rowe J, Paul S, Liang TJ, et al. Human monoclonal antibody to hepatitis $\mathrm{C}$ virus $\mathrm{E} 1$ glycoprotein that blocks virus attachment and viral infectivity. J Virol (2004) 78(13):7257-63. doi:10.1128/ JVI.78.13.7257-7263.2004

74. Meunier JC, Russell RS, Goossens V, Priem S, Walter H, Depla E, et al. Isolation and characterization of broadly neutralizing human monoclonal antibodies to the el glycoprotein of hepatitis C virus. J Virol (2008) 82(2):966-73. doi:10.1128/JVI.01872-07

75. Pantua H, Diao J, Ultsch M, Hazen M, Mathieu M, McCutcheon K, et al. Glycan shifting on hepatitis C virus (HCV) E2 glycoprotein is a mechanism for escape from broadly neutralizing antibodies. J Mol Biol (2013) 425(11): 1899-914. doi:10.1016/j.jmb.2013.02.025

76. Dhillon S, Witteveldt J, Gatherer D, Owsianka AM, Zeisel MB, Zahid MN, et al. Mutations within a conserved region of the hepatitis C virus E2 glycoprotein that influence virus-receptor interactions and sensitivity to neutralizing antibodies. J Virol (2010) 84(11):5494-507. doi:10.1128/JVI.02153-09

77. Morin TJ, Broering TJ, Leav BA, Blair BM, Rowley KJ, Boucher EN, et al. Human monoclonal antibody HCV1 effectively prevents and treats HCV infection in chimpanzees. PLoS Pathog (2012) 8(8):e1002895. doi:10.1371/ journal.ppat. 1002895

78. Chung RT, Gordon FD, Curry MP, Schiano TD, Emre S, Corey K, et al. Human monoclonal antibody MBL-HCV1 delays HCV viral rebound following liver transplantation: a randomized controlled study. Am J Transplant (2013) 13(4):1047-54. doi:10.1111/ajt.12083

79. Wei X, Decker JM, Wang S, Hui H, Kappes JC, Wu X, et al. Antibody neutralization and escape by HIV-1. Nature (2003) 422(6929):307-12. doi:10.1038/ nature 01470

80. Goffard A, Dubuisson J. Glycosylation of hepatitis C virus envelope proteins. Biochimie (2003) 85:295-301. doi:10.1016/S0300-9084(03)00004-X

81. Keck ZY, Angus AG, Wang W, Lau P, Wang Y, Gatherer D, et al. Non-random escape pathways from a broadly neutralizing human monoclonal antibody map to a highly conserved region on the hepatitis C virus E2 glycoprotein encompassing amino acids 412-423. PLoS Pathog (2014) 10(8):e1004297. doi:10.1371/journal.ppat.1004297

82. Li Y, Pierce BG, Wang Q, Keck ZY, Fuerst TR, Foung SK, et al. Structural basis for penetration of the glycan shield of hepatitis C virus E2 glycoprotein by a broadly neutralizing human antibody. J Biol Chem (2015) 290(16): 10117-25. doi:10.1074/jbc.M115.643528

83. Deng L, Ma L, Virata-Theimer ML, Zhong L, Yan H, Zhao Z, et al. Discrete conformations of epitope II on the hepatitis $\mathrm{C}$ virus $\mathrm{E} 2$ protein for antibodymediated neutralization and nonneutralization. Proc Natl Acad Sci U S A (2014) 111(29):10690-5. doi:10.1073/pnas.1411317111

84. Julien JP, Lee PS, Wilson IA. Structural insights into key sites of vulnerability on HIV-1 Env and influenza HA. Immunol Rev (2012) 250(1):180-98. doi:10.1111/imr.12005

85. Fournillier A, Wychowski C, Boucreux D, Baumert TF, Meunier JC, Jacobs D, et al. Induction of hepatitis $C$ virus $\mathrm{E} 1$ envelope protein-specific immune response can be enhanced by mutation of N-glycosylation sites. J Virol (2001) 75(24):12088-97. doi:10.1128/JVI.75.24.12088-12097.2001

86. Liu M, Chen H, Luo F, Li P, Pan Q, Xia B, et al. Deletion of N-glycosylation sites of hepatitis $C$ virus envelope protein E1 enhances specific cellular and humoral immune responses. Vaccine (2007) 25(36):6572-80. doi:10.1016/j. vaccine.2007.07.003

87. Li P, Wan Q, Feng Y, Liu M, Wu J, Chen X, et al. Engineering of N-glycosylation of hepatitis $C$ virus envelope protein E2 enhances $T$ cell responses for DNA immunization. Vaccine (2007) 25(8):1544-51. doi:10.1016/j.vaccine. 2006.09.091

88. Ren Y, Min YQ, Liu M, Chi L, Zhao P, Zhang XL. N-glycosylation-mutated $\mathrm{HCV}$ envelope glycoprotein complex enhances antigen-presenting activity and cellular and neutralizing antibody responses. Biochim Biophys Acta (2016) 1860(8):1764-75. doi:10.1016/j.bbagen.2015.08.007

89. Clarke JL, Paruch L, Dobrica MO, Caras I, Tucureanu C, Onu A, et al. Lettuceproduced hepatitis $\mathrm{C}$ virus E1E2 heterodimer triggers immune responses in mice and antibody production after oral vaccination. Plant Biotechnol J (2017) 15(12):1611-21. doi:10.1111/pbi.12743

90. Li D, von Schaewen M, Wang X, Tao W, Zhang Y, Li L, et al. Altered glycosylation patterns increase immunogenicity of a subunit hepatitis $\mathrm{C}$ virus vaccine, inducing neutralizing antibodies which confer protection in mice. J Virol (2016) 90(23):10486-98. doi:10.1128/JVI.01462-16

91. Zhang M, Gaschen B, Blay W, Foley B, Haigwood N, Kuiken C, et al. Tracking global patterns of $\mathrm{N}$-linked glycosylation site variation in highly variable viral glycoproteins: HIV, SIV, and HCV envelopes and influenza hemagglutinin. Glycobiology (2004) 14(12):1229-46. doi:10.1093/glycob/cwh106

92. Helle F, Duverlie G, Dubuisson J. The hepatitis C virus glycan shield and evasion of the humoral immune response. Viruses (2011) 3(10):1909-32. doi:10.3390/v3101909

Conflict of Interest Statement: The authors declare that the research was conducted in the absence of any commercial or financial relationships that could be construed as a potential conflict of interest.

Copyright (๑) 2018 Lavie, Hanoulle and Dubuisson. This is an open-access article distributed under the terms of the Creative Commons Attribution License (CC BY). The use, distribution or reproduction in other forums is permitted, provided the original author(s) and the copyright owner are credited and that the original publication in this journal is cited, in accordance with accepted academic practice. No use, distribution or reproduction is permitted which does not comply with these terms. 